УДК 37(09) - 053.2

DOI:

Олена Квас, доктор педагогічних наук, професор кафедри загальної педагогіки та педагогіки вищяӧ̈ школи Львівського національного університету імені Івана Франка

\title{
ПРОБЛЕМА ДОСЛІДЖЕННЯ ПІДТРИМКИ МАТЕРИНСТВА І ДИТИНСТВА В УКРАЇНСЬКІЙ ВИХОВНІЙ ТРАДИЦІЇ
}

Стаття присвячена аналізу етнопедагогічних досліджень проблеми підтримки материнства $i$ дитинства в украӥнській виховній традиції. Доводиться, щуо дослідження психологів та дані етнографії про розвиток дітей у різних суспільствах сприяли подоланню панівних довгий час уявлень про дитинство як “натуральну стадію”, щуо володіє певними універсальними для всіх часів і народів властивостями. Будучи сочіокультурним феноменом, дитинство має конкретно-історичний характер та історію розвитку.

Ключові слова: дитинство; материнство; виховна традиція; етнопедагогіка.

תim. 16.

Olena Kvas, Doctor of Sciences (Pedagogy), Professor of the General and Social Pedagogy Department Lviv Ivan Franko National University

\section{THE PROBLEM OF STUDYING SUPPORT OF MOTHERHOOD AND CHILDHOOD IN THE UKRAINIAN EDUCATIONAL TRADITION}

The article is devoted to the analysis of the ethnopedagogical researches on the problem of support of motherhood and childhood in the Ukrainian educational tradition. It turns out that the study of psychologists and ethnographic data on the development of children in different societies contributed to overcoming the dominant long time of representations of childhood as a "natural stage", which possesses certain universal properties for all time and peoples. Being a sociocultural phenomenon, childhood has a specific historical character and a history of development.

The situation of the child in the Ukrainian family of the past was ambiguous. Despite the desire to have children, disparaging attitude towards infertile women, child abuse was often severe, repressive methods of education were used. That childhood was fast-moving. At the age of three, children were deprived of guardianship by the elders, and from the age of four, they were actively involved into working life. Actually, this can be traced in the terminology of the designation of a child of all ages, as discussed above. It was complicated by the lives of illegitimate children, who often did not have any rights. Somewhat better was the situation of orphans. The ethnographic, historical works of the past describe in detail the life of the Ukrainian child. At the same time, we must note that modern ethnopedagogical studies often mimic the Ukrainian family and raise children in it.

That is why, we believe, there is a need for an objective study of the place of the child and the role of childhood in the Ukrainian educational tradition.

Keywords: childhood; motherhood; an educational tradition; ethnopedagogy.

П остановка проблеми. Дитинство це етап онтогенетичного розвитку індивіда, що починається з народженням дитини і закінчується безпосереднім включенням у доросле життя. Дослідження психологів та дані етнографіїпро розвиток дітей урізних суспільствах сприяли подоланню панівних довгий час уявлень про дитинство як “натуральну стадію”, що володіє певними універсальними для всіх часів і народів властивостями.

Насправді, будучи соціокультурним феноменом, дитинство має конкретно-історичний характер та історію розвитку. Головна соціальна функція дитинства, що полягає у підготовці людини до самостійної дорослої праці, визначає специфіку вікової диференціації, тривалість та своєрідність дитинства. На характер і зміст окремих періодів дитинства також впливають конкретні соціальноекономічні й етнокультурні особливості суспільства, в якому живе дитина, i, насамперед, система суспільного виховання [11].

Підходи до розуміння дитинства як педагогічної категорії змінилися тільки протягом останнього часу. Дитинство почали вважати правдоподібним конструктом (у якому досить часто уява переплітається 3 особистими спогадами). Цей конструкт репрезентував певну культуру, яка мала нівелювати відмінності між дітьми - статеві, національні, суспільні, фізичні тощо. На думку деяких зарубіжних дослідників, конструювання дитинства має історичний характер, тому його слід розглядати як ідею про 


\section{ПРОБЛЕМАДОСЛЬЖЕННЯПДТРИМКИ МАТЕРИНСТВАІ ДИТИНСТВА В УКРАЇНСЬКІЙ ВИХОВНІЙ ТРАДИЦІЇ}

те, якими повинні бути діти, і яке це має значення для дорослих через призму суспільно-економічних та культурно-освітніх змін.

Мета статті - окреслити етнокультурні засади підтримки материнства та дитинства в українській виховній традиції XIX - початку XX ст.

Аналіз останніх досліджень і публікацій. Для реконструкції культурно-символічних моделей материнства та дитинства, що існують у культурних традиціях різних народів, важливим $\epsilon$ огляд історичних, етнографічних, соціологічних, психологічних джерел.

Основу для інтерпретації фактів та явищ зі сфери дитинознавства у різних народів становить етнографія. Серед цих матеріалів особливо виділяються праці польського етнографа Г. Бігеляйзена (1855 - 1934) "Мати і дитина в обрядах, віруваннях і звичаях народу польського” [1] та українського етнографа М. Грушевського “Дитина у звичаях і віруваннях українського народа" з коментарями 3. Кузелі [4; 9]. Вони охоплюють широкий віковий діапазон: від вагітності до підліткового віку та мають компаративний характер. Г. Бігеляйзен розглядає етапи дитячого життя у різних народів та в різних культурах від найдавніших часів аж до початку XX ст. М. Грушевський спирається на матеріал (в основному зразки матеріальної культури), зібраний у містечку Суботів та сусідніх слободах (південна Київщина). За словами 3. Кузелі, автор уперше в українській етнографії подивився на життя дитини як на окрему цілість і зібрав широкий матеріал, що охоплює не лише розвиток і зростання дитини від народження до парубочого віку, але й всі заходи перед приходом у світ, іiі парубочий і дівочий вік на початку статевої зрілості, їі пісні, казки, малюнки тощо. При цьому він не обмежився описуванням звичаїв та обрядів, але глянув глибше у душу немовляти і підлітка, у психологію родичів й оточення, серед якого зростає молоде покоління, давши дуже пластичний образ розвитку дитячого тіла й душі. М. Грушевський першим намагався критичним оком глянути на всі прояви дитячого життя, і тому саме від цього дослідження можна датувати серйозні початки студій над дітьми [4].

А вже 3. Кузеля так опрацював ці матеріали, що, за словами I. Франка, “до кожного важнішого моменту у студіях над українською дитиною додавав або пояснення про етнологічні зв'язки сього моменту 3 міжнародними чи місцевими явищами в різних краях і у різних народів, або реєстри книжок, де говориться про такі самі явища. Таким способом зроблено все, що може дати сучасний стан науки для дослідження i вистудіювання тих явищ, таких многоважних для розуміння традиції і життєвих звичок народу” [14].

Серед етнографічних праць з проблем дитини та дитинства на увагу заслуговують також студії М. Дерлиці [5], Н. Заглади [6], Д. Лепкого [10] та ін. Саме Н. Заглада описала явища дитячого побуту, тобто “дитячу субкультуру” і зробила це вперше в українській етнографії.

Виклад основного матеріалу. Насправді, будучи соціокультурним феноменом, дитинство має конкретно-історичний характер та історію розвитку. Головна соціальна функція дитинства, що полягає у підготовці людини до самостійної дорослої праці, визначає специфіку вікової диференціації, тривалість та своєрідність дитинства. На характер і зміст окремих періодів дитинства також впливають конкретні соціальноекономічні й етнокультурні особливості суспільства, в якому живе дитина, i, насамперед, система суспільного виховання [11].

У межах європейської культурної традиції існує кілька різних образів дитини:

a) традиційний християнський погляд, підсилений кальвінізмом, що новонароджена дитина несе на собі печать першородного гріха $\mathrm{i}$ врятувати ії можна лише нещадним придушенням волі, підкоренням батькам та духовним пастирям;

б) точка зору соціально-педагогічного детермінізму, згідно з якою дитина за природою не схильна ні до добра, ні до зла, а $є$ tabula rasa, на якій суспільство чи вихователь можуть написати що завгодно;

в) точка зору природного детермінізму, відповідно до якої характер і можливості дитини визначені до іiї народження; цей погляд типовий не лише для генетики, але й для середньовічної астрології;

г) утопічно-гуманістичний погляд, що дитина народжується доброю і псується лише під впливом суспільства; ця ідея зазвичай асоціюється з романтизмом, але їі захищали також окремі гуманісти епохи відродження, що тлумачили у цьому дусі християнську догму про дитячу невинність [1].

Попри те, що для кожної української сім’ї надзвичайно важливо було мати дітей, ставлення до них не завжди було лагідним. Матір мусила багато працювати, у літній період чимало часу проводила поза межами хати. Немовлята у цей період були біля матері у спеціальних польових колисках, старші діти залишалися вдома самі або під наглядом сестричок (які самі іноді мали $3-4$ роки) чи членів сім’ї, які не могли працювати [4]. Очевидно, що така ситуація спричиняла високий травматизм дітей, а також їхню смертність. 


\section{ПРОБЛЕМАДОСЛДЖЕННЯПІДРИМКИ МАТЕРИНСТВАІ ДИТИНСТВА В УКРАЇНСЬКІЙВИХОВНІЙ ТРАДИЦІЇ}

Зрештою, у тогочасному сільському середовищі не лише України, але й Європи спостерігалося явище високого рівня народжуваності і смертності. Наприклад, протягом XVII - XVIII ст. у західноєвропейських країнах на першому році життя помирали від однієї п'ятої до однієї третьої частини всіх новонароджених. До 20 років доживали менше половини з них [1]. Польський педагог Д. Жолондз-Стжельчик наводить такі статистичні дані: до першого рокужиття помирали $35 \%$ немовлят, до п'ятого - понад $55 \%$, до дорослого віку доживали лише 35\% [2]. Тому ставлення сімей до смерті дитини часто було спокійним [7]: “Бог дав, Бог взяв", її відхід вважався чимось звиклим, нормальним [2].

Діти перебували у повному підпорядкуванні батьків і зобов'язані були у всьому їх слухатися. Аналогічною була ситуація у Західній Свропі. У давній Польщі дитина цілком підпорядковувалася батькові. Батьківська влада була настільки великою, що він міг вирішувати про свободу, життя і смерть членів родини. Він свою дитину міг продати, вбити чи віддати в заставу. Прийняття християнства дещо поліпшило становище дитини, проте влада батька залишалася такою ж сильною i ще більше погіршилося становище незаконнонароджених дітей [2].

У працях з української етнопедагогіки М. Стельмаховича, Є. Сявавко [12] робилася спроба виокремити методи виховного впливу на дитину. Зокрема, серед таких називалися схвалення, переконання, навіювання, позитивний приклад. Але більш ранні етнографічні праці, зокрема М. Грушевського [4], Н. Заглади [6], вказують на те, що часто у сім'ї використовувалися репресивні методи стосовно дитини: сварка, погрози, залякування, прокльони, фізичні покарання. Починаючи з другого року життя дитини, фізичні покарання уже ставали одним із поширених методів виховання. Їх застосовували щодо дитини, яка у чомусь провинилася. Вважалося, що якщо тих не бити, “то так воно і виросте не по людськи”. Часто слово “бійка" вживалося замість "наука" [4]. Власне, на доцільність використання покарань у вихованні вказуть і народні прислів'я: “Діти люби, а за прутину держи”, “Хто дітям потаче, той сам плаче”, “Дитині дай волю, то сам підеш у неволю”.

Але незважаючи на брак материнської уваги, використання у вихованні покарань, ставлення до батьків, зокрема, матері, в українській родині завжди було шанобливим. У народній свідомості образ матері оточений ореолом святості. Це відображено в усній народній творчості: "Мати однією рукою б’є, а другою гладить”, “Материні побої не болять", "Рідна мати високо замахує, а помалу б'є”, “Материн гнів, як весняний сніг: рясно випаде, та скоро розтане”. О. Кісь зауважує, що ці прислів'я не мають смислових антиподів [8].

Відхилення від нормального анатомічного еталону фіксувалося у назві “вирід”, “одміна” / “відміна”. Потворні недорозвинуті немовлята, німі, сліпі, кульгаві діти вважалися у поляків справою злих духів, спровокованою загляданням вагітною, людським прокляттям, Божою карою чи пересторогою. Середньовічні хроніки, подаючи описи таких народжених у різних сторонах світу, трактували їх як передбачення мору, війни чи інших нещасть. В українців народження неповносправної дитини вважалося карою Божою або наслідком того, що матері, яка з тією дитиною ходила, було відмовлено у певному бажанні. Македонці вважали появу дитини 3 певними вадами знаком Божого прокляття, що є розплатою за гріхи родини. Загалом діти з особливими потребами у низькоосвічених європейських народів зазнавали презирства. В деяких окраїнах Росії таких істот вбивали, в інших послуговувалися частинами їхнього тіла для ворожіння. У диких народів виродків позбавляли життя відразу після народження [3].

Очевидно, що саме хворі діти, позбавлені належної медичної допомоги, помирали найчастіше. Вони були великим тягарем для сім'̈і, проте в Україні, де дітовбивство було великим гріхом, протягом XIX ст. це явище не спостерігалося [15].

Народження таких дітей вимагало “коригування” наявних аномалій, відповідно до анатомічного (стереотипного) взірця, символічними засобами - шляхом виконання певних ритуальномагічних дій [13]. Наприклад, майже на всій території України вірили, що “відьма” поверне сім'ї рідну дитину, якщо до “відміни” ставитися суворо, скажімо, пропонувалося покласти дитину на гній і бити березовими різками, доки відьма не прилетить та не забере свою дитину, а натомість принесе справжню [10]. Результатом таких дій часто ставала смерть дитини або ще більше каліцтво.

У сім'ях народжувалися також діти, що походили 3 нешлюбних зв'язків. Народження позашлюбних дітей, безбатченків засуджувалося, оскільки позбавляло дитину гармонійності в розвитку, примушувало іiі страждати [13].

Католицькою церквою виділялися такі категорії позашлюбних дітей: природні діти (liberi naturales), коли батьки не були родичами, але й не були пошлюбленими, позашлюбні діти (ех 


\section{ПРОБЛЕМАДОСЛДЖЕННЯПЦТРИМКИ МАТЕРИНСТВАІ ДИТИНСТВА В УКРАЇНСЬКІЙВИХОВНІЙ ТРАДИЦЇ̈}

adulterio nati), діти з кровних зв'язків (incestuosi) i врешті, діти тих, хто перебував у духовному сані чи був покликаний дотримуватися целібату (ех sacrilegio geniti) [2].

Відхилення від соціального нормативу, тобто народження поза шлюбом, фіксувалося у таких назвах, як “байстря”, “байстрюк”, “найдух”, “копил”, “нажирована”, “нажитна” (дитина) [2], “букарт”, “жаливник”, “бенькарт” (в українців) [2], "bękart", "bastard", "wylegańca”, "pokrzywnik" (y поляків) [2] та визначало певне специфічне ставлення громади до неї.

Більшість байстрюків були дітьми самотніх жінок, проте певна група були дітьми не шлюбного чоловіка, а походили з позашлюбних зв'язків. Їхня кількість зростала у період воєн, маршів і стояння військ. Становище таких дітей було складним. Вони були безправними, а їхнє походження їм часто нагадувалося. Як правило, такі діти позбавлялися права носити прізвище батька чи претендувати на спадщину, що залишалася після нього. Навіть якщо батьки такої дитини після іiі народження одружувалися, вона залишалася незаконнонародженою. У подальшому вона несла “тавро неповноцінності”, не мала права обиратися до громадського уряду, у неї виникали труднощі при одруженні [2].

Такі діти народжувалися у різних середовищах: не лише у селянських родинах, але й у панських палатах, у тому числі королівських. Проте якщо для заможних чоловіків та жінок факт наявності позашлюбних дітей не схвалювався, але і не був трагедією, для бідних жінок це було справжньою драмою. Їх засуджувало оточення, а іноді таких жінок виганяли за межі села. Однак найбільшим тягарем для них ставало самотнє виховання дітей.

У найкращому становищі перебували діти заможних чоловіків, які у законному шлюбі не мали дітей. Це особливо стосувалося синів, рідше-дочок.

Щоправда, існує думка, що в язичницькій традиції шлюбні та позашлюбні діти мали рівні права, і лише прийняття християнства погіршило становище останніх.

У католицькій традиції прослідковувалися дві тенденції: перша закликала до поліпшення ситуації позашлюбних дітей, а друга, навпаки, приймала їх неохоче. У канонічному праві переважала друга тенденція, коли через дискримінацію позашлюбного потомства здійснювався вплив на родичів, що жили у гріху.

У буденному житті позашлюбні діти теж стикалися $з$ постійною дискримінацією. Уже від моменту народження частим явищем було дітовбивство або покидання дітей, чого не було у законних шлюбах.
Власне, намагання позбутися дитини могло 3'явитися ще до іiі народження. Тоді майбутня мати зверталася до знахарок, щоб отримати відповідне зілля або ж приймала гарячі ванни, чи піднімала важкі речі. Зазвичай такі заходи не допомагали, тому вже після народження дитини iii вбивали шляхом задушення, переламування хребта чи втоплення. В окремих випадках смерть дитини викликалася неналежною опікою. Навіть сувора кара за дітогубство не зупиняла самотніх матерів.

В українській виховній традиції дітогубство було найстрашнішим гріхом [13]. Вважалося, що після смерті на жінку чекає страшна кара: на тому світі вона вічно буде їсти своїх ненароджених дітей. Більше того, народна мораль українців уже саме намагання запобігти дітонародженню трактувала важким гріхом. Тому в другій половині XIX ст. - першій половині XX ст. жінки здебільшого не переривали вагітності, навіть якщо народження дитини було небажаним [15]. Меншим гріхом вважалися дії, спрямовані на тимчасову контрацепцію.

Наступним важливим моментом у людському житті були хрестини та надання імені. Церква приймала усіх дітей, проте часто позашлюбних священик називав дивними, рідко вживаними іменами. Такий звичай побутував не лише в українців, але й у поляків, німців, пермяків тощо. Прикладом таких імен були Фтеопумп, Онисифор, Амфилох, Фіфрона, Гликерія [15], або ж Титус, Касьян, Герменегільда, Спіридіон, Панталеон тощо.

Проте всупереч безправному становищу незаконнонароджених дітей, у народі вважалося, що їнє народження є легким, а самі вони щасливі. Такі вірування притаманні слов'янським та германським народам.

Було дуже почесною місією ставати хрещеними батьком та матір'ю таким дітям. Зокрема, так стверджували кашуби західнослов' янський народ, що проживає на північному заході Польщі. Чехи вважали, що бути кумами неодруженої жінки передвіщає щастя. А от німці та румуни були переконані, що це допомагає кумам щасливо та вдало одружитися у майбутньому. В Польщі та Україні ж вірили, що у господарстві кумів буде добре вестися худоба.

Ян Станіслав Бистронь (1892 - 1964) польський етнограф та соціолог, бачив у звичаєві цієї категорії зв'язок, який встановило первісне мислення між плідністю поза шлюбом, а відтак незвичайним і благополучним завершенням.

Осудливим в українців було ставлення до зведених дівчат. Якщо дівчина позбулася честі 


\section{ПРОБЛЕМАДОСЛДЖЕННЯПДТРИМКИ МАТЕРИНСТВАІ ДИТИНСТВА В УКРАЇНСЬКІЙ ВИХОВНІЙ ТРАДИЦІЇ}

до шлюбу, то не мала права одягати вінок. До збезчещеної дівчини нерідко застосовувалися фізичні покарання, їй обрізали косу, водили разом 3 хлопцем, що звів іiі, селом, обмазували ворота дьогтем, надягали хомут й запрягали до воза. На Бойківщині побутував звичай “зганьблену дівку вести на купу”: посеред села насипали купу каміння, виводили на неї дівчину і доручали найстаршому чоловікові в селі покрити ії голову хусткою.

На всій території України найбільш вживаним терміном на означення дівчини, що народила нешлюбно, був “покритка". У різних етнографічних районах ще казали: “копилка”, “завилася”, “покрилася”, “скозачилася” тощо [15].

Покритка не мала права бути у молодіжній дівочій громаді, ходити з непокритою головою, стояти в церкві поруч 3 дівчатами. Вона була позбавлена можливості брати участь у багатьох ритуалах, зокрема, випіканні весільного короваю, виконанні функцій повитухи тощо. Вона продовжувала жити у своїй сім’ї, над нею могли посміятися, при нагоді кинути докір, а іноді й поспівчувати. За народною мораллю, акт “покриття" мав на меті покарати винну і тим відвернути інших від подібних вчинків.

М. Стельмахович зауважував, що “поведінці легковажної дівчини... виправдання немає. Але 3 батьків не знімається провина за погану поведінку сина чи дочки. Томуй в уста покритки народ вклав такі слова: “Оце на тобі, моя ненько, за твою науку: колихала ти мене, колихай онуку”, “Гайкалайка пішла на долинку, принесла дитинку”, “Оце тобі, тату, за твою науку: сядь собі у запічку, колиши онуку" [12].

Піклувався народ-вихователь і про долю дитини-сироти. Їй присвячено чимало слів співчуття: “За сиротою журба за журбою”, "Сиротою жити - сльози лити”, "Ніхто не бачить і не чує, як сирота плаче і горює”, “Сироту лають і б’ють, а плакати не дають”, “Сироті хоч з моста та в воду”. Зазначаючи, як важко жити дітям “без роду, без плем'я - без привіту, без совіту”, народ ніколи не втрачав надії на поліпшення їхнього становища (“Сирітська сльоза не капає дарма”, “У сироти на подвір'ї сонце засвітить”).

У Західній Європі для сиріт створювалися притулки. Вже цезар Юстиніан Великий (527 265) організував orphanotropeia - притулок для сиріт та покинутих дітей. У Середні віки подібні заклади створювалися насамперед Церквою. У 1204 р. у Римі папа Іннокентій III заснував притулок Святого Духа. Загалом Церкві належали 1250 таких закладів по всьому світі, вихованцями яких були здебільшого діти, покинуті, віддані на виховання батьками, незаконнонароджені та сироти. Незважаючи на піклування про вихованців, смертність у цих закладах була дуже високою. Найбільше немовлят помирали у віці до одного року. Причиною були найчастіше інфекційні захворювання, брак ліків, а також вроджені вади.

Долею покинутих дітей турбувалася й міська влада. Так, у 1542 р. у Гданську було створено дитячий будинок, до якого приймалися діти за певну оплату. Зрозуміло, що догляд за ними тут був кращим, ніж у притулках, але доступу до них діти бідноти не мали.

У XVIII ст. притулок для покинутих дітей існував і у Львові під егідою сестер-шариток [2].

Проте для українців більш традиційною була опіка над дітьми-сиротами окремих сімей названих батьків. В українській етнопедагогіці велика увага приділяється їхньому вибору. До опікунів ставилися дуже високі вимоги, адже замінити батьків нелегко (“Добра мачуха, та все ж не рідна мати”). Опікуном мала бути людина авторитетна, доброзичлива, вимоглива і чесна, з добрим та щирим серцем, пройнята любов'ю до дітей і готовністю виховувати чужу дитину як власну. Здебільшого опікуном ставав близький або далекий родич (“Свій як не заплаче, то хоч скривиться”, “До свого роду хоч через воду”) або бездітна сім'я, яка має бажання всиновити чи удочерити сироту. Нерідко сироту брала i багатодітна сім'я, бо “де шість, там і сьоме пристроїться” [2]. Усиновлену дитину називали “годованець”, “годованик”, “вихованець”, “приймак” та наділяли практично усіма правами рідної дитини [15].

Висновок. Отже, становище дитини в українській родині минулого було неоднозначним. Незважаючи на бажання мати дітей, зневажливе ставлення до безплідних жінок, поводження 3 дитиною часто було суворим, застосовувалися репресивні методи виховання. Саме дитинство було швидкоплинним. Уже з трирічного віку діти були позбавлені опіки з боку старших, а 3 чотирирічного - активно включалися у трудове життя. Власне, це можна простежити за термінологією на позначення дитини різного віку, про що мова йшла вище. Складним було життя незаконнонароджених дітей, які часто не мали жодних прав. Дещо кращим було становище сиріт. Етнографічні, історичні праці минулого детально описують побут української дитини. Водночас мусимо відзначити, що сучасні етнопедагогічні дослідження часто міфологізують українську родину та виховання дітей у ній.

Саме тому, вважаємо, $\epsilon$ потреба в об'єктивному дослідженні місця дитини і ролі дитинства в українській виховній традиції. 


\section{ПРОБЛЕМАДОСЛДЖЕННЯПЦТРИМКИ МАТЕРИНСТВАІ ДИТИНСТВА В УКРАЇНСЬКІЙ ВИХОВНІЙ ТРАДИЦІЇ}

\section{ЛITEPATУРА}

1. Biegeleisen H. Matka i dziecko w obrzędach, wierzeniach i zwyczajach ludu polskiego / H. Biegeleisen. - Lwów: Ateneum, 1927. - 414 s.

2. Żołądź-Strzelczyk D. Dziecko w dawnej Polsce / D. Żołądź-Strzelczyk. - Poznań: Wydawnictwo Poznańskie, 2006. - $354 \mathrm{~s}$

3. Ганенко М. Семейно-имущественные отношения крестьянского населения в Елисаветградском уезде. (Материалы по обычному праву) / М. Ганенко // Степ. Херсонский беллетристический сборник. Херсон. СПб.: тип. В.С. Балашева, 1886. -С. 136-159.

4. Грушевський М. Дитина у звичаях і віруваннях українського народу / М. Грушевський. - К. : Либідь, 2006. $-256 \mathrm{c}$.

5. Дерлиця М. Селянські діти. Етнографічний нарис / М. Дерлиця // Етнографічний збірник НТШ. - 1898. T. 5. $-1898 .-$ C. 121-136.

6. Заглада Н. Побут селянської дитини: матеріали до монографії с. Старолісся / Н. Заглада. -К., 1929. - 180 с.

7. Зидер Р. Социальная история семьи в Западной Европе (конец XVIII - XX вв.) / Р. Зидер; [пер. с нем.] М. : Владос, 1997. -302 с.

8. Кись О. Материнство и детство в украинской традиции: деконструкция мифа / О. Кись // Социальная история. Ежегодник 2003. Женская и гендерная история / [под ред. Н. Пушкаревой]. - М. : "Российская политическая энциклопедия", 2003. - С. 156-172.

9. Кузеля 3. Про студії над дїтьми / 3. Кузеля // Матеріяли до українсько-руської етнольогії. - Львів, 1907. - T. IX. - C. XI-XXIII.

10. Лепкий Д. Деякі вірування про дитину / Д. Лепкий // Зоря. - 1886. - № 15-16. - С. 77-269.

11. Педагогічний словник / [за ред. дійсного члена АПН України М.Д. Ярмаченка]. - К.: Педагогічна думка, 2001. $-516 \mathrm{c}$.

12. Стельмахович М.Г. Українська народна педагогіка / М.Г. Стельмахович. -К.: І3МН, 1997. -232 с.

13. Українське народознавство / [за ред. С.П. Павлюка; передм. М.Г. Жулинського]. - К.: Знання, 2006. $-568 \mathrm{c}$.

14. Франко І. Рецензія на працю “Дитина в звичаях і віруваннях українського народа" / І. Франко // Дитина у звичаях і віруваннях українського народу / М. Грушевський. - К.: Либідь, 2006. - С. 8.

15. Щербак I.М. Діти в обрядах та віруваннях українців XIX - початку XX ст. (статевовіковий аспект традиційної культури): автореф. дис... канд. іст. наук: спец. 07.00.05 / І.М. Щербак; НАН України. Ін-т мистецтвознав., фольклористики та етнології ім. М.Т. Рильського. - К., 2004. - 18 с.

\section{REFERENCES}

1. Biegeleisen, H. (1927). Matka i dziecko wobrzkdach, wierzeniach $i$ zwyczajach ludu polskiego [A mother and a child in rites, beliefs and customs of the Polish people]. Lwiw: Ateneum, 414 p. [in Polish].
2. Zoladz-Strzelczyk, D. (2006). Dziecko w dawnej Polsce [A child in ancient Poland]. Poznac: Wydawnictwo Poznacskie, 354 p. [in Polish].

3. Ganenko, M. (1886). Semeyno-imushchestvennye otnosheniya krestyanskogo naseleniya $v$ Yelisavetgradskom uezde. (Materialy po obychnomu pravu) [A familyand property relations of the peasant population in Elisavetgrad district. (the materials of customary law)]. Kherson. Saint Petersburg: V.S. Balashev Publ.,pp. 136-159. [in Russian].

4. Hrushevskyi, M. (2006). Dytyna u zvychaiakh $i$ viruvanniakh ukrainskoho narodu [A child in the customs and beliefs of the Ukrainian people]. Kyiv: Lybid, 256 p. [in Ukrainian].

5. Derlytsia, M. (1898). Selianski dity. Etnohrafichnyi narys [Peasant children. Ethnographic essay]. Ethnographic collection, Vol.5, pp. 121-136. [in Ukrainian].

6. Zahlada, N. (1929). Pobut selianskoi dytyny: materialy do monohrafii s. Starolissia [The life of a peasant child: materials for a monograph Starolissya village]. Kyiv, 180 p. [in Ukrainian].

7. Zider, R. (1997). Sotsialnaya istoriya semi v Zapadnoy Yevrope (konets XVIII - XX vv.)[ The social history of the family in Western Europe (the end of the 18th and 20th centuries)]. R. Zider; (Translation from German). Moscov: Vlados, 302 p. [in Russian].

8. Kis, O. (2003). Materinstvo i detstvo v ukrainskoy traditsii: dekonstruktsiya mifa [Maternity and childhood in the Ukrainian tradition: the deconstruction of the myth]. Social history. Yearbook 2003. Women's and Gender History. (Ed.). N. Pushkarevoy. Moscov: "Rossiyskaya politicheskaya entsiklopediya", pp. 156-172. [in Russian].

9. Kuzelia, Z. (1907). Pro studii nad ditmy [About studios over children]. The materials for the UkrainianRuska ethnology. Lviv, Vol.9, pp. 11-23. [in Ukrainian].

10. Lepkyi, D. (1886). Deiaki viruvannia pro dytynu [Some beliefs about the child]. Zoria. No.15-16, pp. 77269. [in Ukrainian].

11. Yarmachenko, M. D. (Ed.). (2001). Pedahohichnyi slovnyk [Pedagogical dictionary].Kyiv: Pedahohichna dumka, 516 p. [in Ukrainian].

12. Stelmakhovych, M. H. (1997). Ukrainska narodna pedahohika [Ukrainian folk pedagogy]. Kyiv: IZMN, 232 p. [in Ukrainian].

13. Pavliuk, S. P. (2006). Ukrainske narodoznavstvo [Ukrainian ethnology]. Kyiv: Znannia, 568 p. [in Ukrainian].

14. Franko, I. (2006). Retsenziia na pratsiu "Dytyna v zvychaiakh i viruvanniakh ukrainskoho naroda" [Review of work "A child in the customs and beliefs of the Ukrainian people"]. Kyiv: Lybid, p. 8. [in Ukrainian].

15. Shcherbak, I. M. (2004). Dity v obriadakh ta viruvanniakh ukraintsiv XIX - pochatku XX st. (statevovikovyi aspekt tradytsiinoi kultury) [Children in the rites and beliefs of Ukrainians of the 19th and early 20th centuries. (the sex and age aspect of traditional culture)]. Institute of Art Studies, Folklore Studies and Ethnology named after Maksym Rylskiy. Kyiv, 18 p. [in Ukrainian].

Стаття надійшла до редакції 19.10.2018

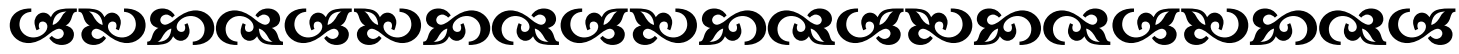

